\title{
DLA JAKICH DZIECI ALICJA? ALICJA DLA DZIECI KWIATÓW! MUZYCZNE PRZETWORZENIA ALICJI W KRAINIE CZARÓW PRZEZ KONTRKULTURĘ LAT SZEŚĆDZIESIĄTYCH
}

\author{
KATARZYNA KOĆMA ${ }^{1}$ \\ (Uniwersytet Jagielloński w Krakowie)
}

Słowa kluczowe: Alicja w Krainie Czarów, dzieci kwiaty, kontrkultura, lata 60., muzyka Key words: Alice in Wonderland, flower power, counterculture, the 60s, music

\begin{abstract}
Abstrakt: Katarzyna Koćma, DLA JAKICH DZIECI ALICJA? ALICJA DLA DZIECI KWIATÓW! MUZYCZNE PRZETWORZENIA ALICJI W KRAINIE CZARÓW PRZEZ KONTRKULTURĘ LAT SZEŚĆDZIESIĄTYCH. „PORÓWNANIA” 19, 2016. T. XIX. S. 183-199. ISSN 1733-165X. Niniejszy artykuł przedstawia muzyczne przetworzenia Alicji w Krainie Czarów Lewisa Carrolla przez kontrkulturę lat 60 . Autorka pokazuje, jak psychodelia w sztuce i kulturze tamtego okresu sprawiła, że utwór zaczął być postrzegany jako zapis doświadczenia narkotycznego. Analizując, co w tekstach piosenek dzieje sięz takimi bohaterami,jak - na przykład Alicja, Szalony Kapelusznik, Pan Gąsienica czy Biały Królik, autorka wskazuje na transformacje, jakiej uległy postaci w piosenkach The Beatles, Jefferson Airplane, The IncredibleString Band, The Monkees czy Toma Northcotta. Piosenki podzielono na trzy części: Alicja - Ta, Która Wie, Alicja - Ta, Której Nie Ma i Mieszkańcy Krainy Czarów.
\end{abstract}

\begin{abstract}
Katarzyna Koćma, IS ALICE NEEDED BY ANY FLOWERS? ALICE IS NEEDED BY FLOWER POWER! MUSICAL TRANSFORMATIONS OF ALICE IN WONDERLAND BY THE COUNTERCULTURE OF THE 60S. „PORÓWNANIA” 19, 2016. VOL. XIX. P. 183-199. ISSN 1733-165X. The paper presents musical development of Alice in Wonderland by Lewis Carroll from a perspective of the counterculture of the 60s. The authoress shows how the existence of psychodelia in arts and culture of that decade made Carroll's work a kind of record of the so called "trip". Trying to analyze what happens to the lyrics' protagonists, for example Alice, Mad Hatter, Caterpillar or White Rabbit, the authoress indicates the transformations of them in songs of The Beatles, Jefferson Airplane, The Incredible String Band, The Monkees or Tom Northcott. The lyrics were divided into three parts: The Alice Who Knows, The Alice Who Is Gone and The Wonderland's Inhabitants.
\end{abstract}

1 E-mail: katarzynakocma@gmail.com. 


\section{Lata sześćdziesiąte - przekraczanie wrót percepcji}

Dekada fantazji oraz powrotu surrealizmu, bujnie rozkwitającej intertekstualności literackiej, malarskiej czy muzycznej, czas, w którym wiele grup społecznych i artystycznych zaczyna powoływać do istnienia eksperymentalne komuny - tak można opisać lata sześćdziesiąte, w których prym wiodą takie dzieła literackie, jak Obcy w obcym kraju Roberta A. Heinleina, Wilk stepowy Hermana Hessego, utwory Jacka Kerouaca i Williama S. Burroughsa oraz tytułowa Alicja w Krainie Czarów Lewisa Carrolla. To z nich czerpie się najwięcej. Powieści te nie tylko są czytane i analizowane, lecz także ulegają transformacji, zmieniając kanon kontrkultury i kultury popularnej.

Era dzieci kwiatów nie zważa na czas powstania oryginału. Jeśli tekst jest wystarczająco odważny, dziwny, niepokojący, symboliczny, ma szansę wejść do kontrkulturowego kanonu. Tak stało się z dziełem Lewisa Carrolla, które zostało niemal zawłaszczone przez lata sześćdziesiąte. Wszyscy czytają wówczas Alicję w krainie czarów i czerpią z niej inspirację, gdyż pewne motywy - Szalony Kapelusznik, królicza nora czy palący fajkę Pan Gąsienica - doskonale wpisują się w konwencję tak zwanej psychodelii, nurtu czołowego dla omawianej dekady. Również struktura utworu, język, wielopoziomowe znaczenia zakodowane w utworze są atrakcyjne dla osób poszukujących nowych doznań estetycznych. Okazuje się nagle, że niezwykłe przygody Alicji są odczytywane jako zapis tzw. tripu narkotycznego lub interpretuje się je w duchu psychoanalizy Zygmunda Freuda. Alicja z lat sześćdziesiątych nie jest już książką dla dzieci. Staje się raczej podręcznikiem objaśniającym, jak przejść na drugą stronę, jak przekroczyć wrota percepcji. Między powieścią Carrolla a zjawiskiem psychodelii stawia się znak równości.

\section{Psychodelia w sztuce i kulturze}

Oficjalnie po raz pierwszy terminem psychodelia posłużył się w 1956 roku psychiatra, Humphry Osmond, który nazwał tak środki halucynogenne (Murray 419). Sam wyraz wywodzi się z greckiego złożenia psychē (

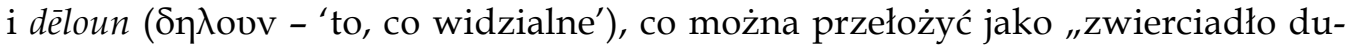
szy" (Online Etymology Dictionary, hasło "psychedelic"). Jednak słowem zbudowanym na tym rdzeniu określano nie tylko psychodeliki, a więc rodzaj środków narkotycznych wywołujących halucynacje, lecz także pewien bliski halucynacji sposób opisu świata przedstawianego, który często (lecz nie zawsze) zaczął pojawiać się w literaturze, muzyce, filmie czy w sztukach wizualnych pod wpływem takich środków.

Najsłynniejszymi przejawami psychodelii w kontrkulturze są Acid Tests eksperymenty z narkotykiem zwanym LSD, przeprowadzane przez Timothy'ego 
Leary'ego i jego grupę performatywną, mającą cechy sekty - Merry Pranksters, oraz happeningi odbywające się w 1967 roku w Haight-Ashbury, artystycznej dzielnicy San Francisco, znane pod nazwą Summer of Love (Wolfe). Do znanych realizacji sztuki psychodelicznej zalicza się także prace Roberta Crumba, który projektował plakaty hippisowskich zespołów, między innymi Big Brother And The Holding Company (Holm). W latach sześćdziesiątych pod wpływem eksperymentów z użyciem środków halucynogennych narodził się także nurt tzw. rocka psychodelicznego, który reprezentowali między innymi The Doors, Jefferson Airplane czy Grateful Dead.

Według klasyfikacji Erowid Center ${ }^{2}$ psychodeliczne doświadczenie dzieli się na pięć etapów: etap pierwszy to postrzeganie wyraźniejszych kolorów, słyszenie dźwięków o wyższym natężeniu, w drugim dochodzi do zaburzenia kształtów, trzeci cechuje się kolorowymi halucynacjami, poczuciem synestezji, wrażeniem zaburzenia czasu i przestrzeni, etap czwarty wiąże się z poczuciem rozpadu jaźni i zaburzeniami tożsamości, piąty zaś określa się jako stan bliski nirwanie (The psychodelic experience, źródło elektroniczne). Klasyfikacja ta, choć związana ze stanami występującymi po zażyciu psychodelików, z powodzeniem znalazła zastosowanie w sztuce, muzyce czy poezji, gdzie efekt psychodeliczny artysta osiąga za pomocą operowania kontrastowymi kolorami, dźwiękami o zmiennym natężeniu czy przez przedstawienie rozpadu jaźni.

Psychodelia jednak często bywa rozumiana intuicyjnie. W potocznym ujęciu psychodeliczne doznanie przypomina sen, wiąże się z dużym poczuciem wyobcowania, absurdu, fantastyki, bywa groteskowe, może być mroczne, lecz i pełne barw, kolorów. To często pulsowanie świateł, gra dźwiękami, rozbudowane metafory, których nie da się do końca zrozumieć. Przede wszystkim jednak psychodelia to poczucie dziwaczności i grozy istnienia, egzystencjalizm zabarwiony fantastyką.

\section{Alicja w Krainie Czarów w epoce dzieci kwiatów}

Rozpad języka, zaburzenia percepcji, stan zbliżony do marzenia sennego, tajemnicze zwierzęta i postaci, irracjonalność, sprzeniewierzenie się zasadom logiki, halucynogenne grzyby, Biały Królik czy podejrzanie wyglądający napój, którego etykieta głosi: „wypij mnie”, to tylko niektóre elementy świata przedstawionego Alicji w Krainie Czarów. Nic dziwnego, że w latach sześćdziesiątych zyskała ona status dzieła kultowego.

Thomas Fensch, autor opracowania Alice in Acidland uważnie analizuje miejsca, w których Carroll pisał - zdaniem autora - o doświadczeniu narkotycznym (Fensch).

2 Ciesząca się szacunkiem i pełniąca rolę opiniotwórczą amerykańska organizacja, badająca środki halucynogenne i skutki ich zażywania, propagująca wiedzę na temat narkotyków. 
W Hippie Dictionary znajdziemy natomiast hasło Feed your head, które w Alicji wypowiada Mysz; w slangu dzieci kwiatów oznacza ono po prostu zażywanie narkotyków (McCleary 176). Z kolei w niezbędniku każdego hippisa (The Hippie Handbook: How to Tie-Dye a T-Shirt, Flash a Peace Sign, and Other...) wśród pomysłów na psychodeliczny mural pojawia się między innymi, obok portretu JFK czy pacyfki, scena z Alicji w Krainie Czarów (Cain 139). W Collectible '70s: A Price Guide to the Polyster Decade możemy zaś przeczytać, iż za sprawą scen rozmowy Alicji z Panem Gąsienicą motyw grzybów stał się wyjątkowo nośny w kulturze popularnej - przedstawiano go na pocztówkach, koszulkach czy plakatach (Goldberg 92). W latach siedemdziesiątych dzieło Carrolla spopularyzowały też utrzymany w psychodelicznej konwencji film Disneya i pamiętnik ",anonimowej” narkomanki zatytułowany Go Ask Alice.

Przejawy wzmożonego zainteresowania formacji kontrkulturowej utworem sprzed blisko wieku obserwować można już w latach sześćdziesiątych. Jego początków należy upatrywać $\mathrm{w}$ twórczości zespołów muzycznych na czele z prawdopodobnie najsłynniejszym - The Beatles.

\section{Reinterpretacje dzieła Carrolla w tekstach muzyki popularnej lat sześćdziesiątych}

Muzycznych interpretacji Alicji, zwłaszcza z końca lat sześćdziesiątych i począt$\mathrm{ku}$ lat siedemdziesiątych, jest naprawdę wiele. Nie wszystkie z nich są popularne, nie wszystkie zasługują na uwagę. Warto jednak pamiętać, że muzyczną interpretację powieści Carrolla zaproponowali nie tylko Beatlesi i Jefferson Airplane, ale także wiele innych zespołów, jak choćby The Incredible String Band czy The Monkees.

Analiza tej twórczości prowadzi do obserwacji pewnej prawidłowości - część utworów pisana jest z punktu widzenia Alicji (nawet w pierwszejosobie), część mówi o Alicji, której już nie ma, inne ujmują temat z perspektywy mieszkańców Krainy Czarów. W niniejszym artykule skupiłam się przede wszystkim na tych, w których Alicja - czy to w bezpośrednim odwołaniu, czy jako symbol - pojawia się w utworze bezpośrednio, odrzuciłam natomiast muzyczne narracje musicalowe związane z tematem w niewielkim stopniu oraz proste i oczywiste teksty, które niewiele wnoszą do tematu muzycznej alicjologii.

Ta część rozważań została podzielona na trzy części: część 1: Alicja - Ta, Która Wie (White Rabbit [White Rabbit, źródło elektroniczne], Lucy In The Sky With Diamonds [Lucy, źródło elektroniczne]), część 2: Alicja - Ta, Której Nie Ma (Alice Is A Long Time Gone [Alice, źródło elektroniczne], Who Planted Throns In Miss Alice's Garden? [Who Planted, źródło elektroniczne], Through The Looking Glass [Through The Looking Glass, źródło elektroniczne]), część 3: Mieszkańcy Krainy Czarów (I Am The Walrus [I Am The Walrus, źródło elektroniczne]). 


\section{Alicja - Ta, Która Wie}

Dla niektórych wykonawców muzyki lat sześćdziesiątych postać Alicji - niekoniecznie jako małej dziewczynki - staje się kluczowa. Alicja jest protagonistką, przewodniczką po dziwacznej Krainie Czarów. To ona zna jej reguły, posiada dostęp do symbolicznych znaczeń, które kryją się pod postaciami bohaterów bądź zdarzeń. Ta niepozorna, zagubiona dziewczyna staje się kobiecą wersją upersonifikowanej wiedzy mistycznej. Możemy nazwać ją Tą, Która Wie. Tak dzieje się w przypadku chyba najsłynniejszej piosenki - White Rabbit grupy Jefferson Airplane. Utwór został wydany na płycie Surrealistic Pillow (już sam tytuł albumu jest wymowny!), która ukazała się na rynku 24 czerwca 1967 roku, w czasie trwania Lata Miłości. Tekst stał się tak inspirujący, że w filmie Las Vegas Paramo pojawia się oparta na nim scena, a Beatrice Sparks zaczerpnęła z refrenu tytuł dla stylizowanej na pamiętnik książki Go Ask Alice.

Opowieść w piosence zaczyna się nie w momencie, gdy nastolatka (trzeba powiedzieć, że tutaj Alicja nie jest niewinną dziewczynką) wpada w króliczą norę (choć tytuł utworu mógłby to sugerować), lecz gdy przyjmuje tajemnicze pigułki. W oryginalnej wersji dziewczynka zjada ciastko i wypija napój, znajdując się już w króliczej norze. Dopiero wówczas proporcje jej ciała ulegają zmianie. Lata sześćdziesiąte, zafascynowane LSD, zastąpiły produkty naturalne syntetyczną tabletką, Alicja nie posila się więc w sposób tradycyjny, lecz za pomocą nowoczesnego substytutu pokarmu i napoju - przyjmując jednocześnie oba składniki o wykluczających się właściwościach.

Pod wpływem substancji halucynogennych perspektywa odczucia własnego ciała, w tym jego proporcji, zostaje zaburzona. „One pill makes you larger, one pill makes you small” (Jedna pigułka sprawi, że urośniesz, jedna pigułka sprawi, że zmalejesz ${ }^{3}$ ) - głosi tekst, lecz Alicja nie ogranicza się do zażycia dwóch tabletek (być może LSD oraz innego narkotyku bądź środka halucynogennego, lub też środka likwidującego jego działanie).

Dziewczyna przyjmuje dodatkowo trzecią pigułkę (a raczej pigułki, w liczbie mnogiej): "And the ones that mother gives you / Don't do anything at all" (A te, które daje ci matka / Nie robią nic w ogóle). Czym jest tajemniczy trzeci środek? Jak można przeczytać w serwisie Songfacts, pigułka oznacza „nic”, rodzaj bezużytecznej przestrogi, którą matki dawały córkom podczas seksualnej rewolucji (Songfacts, źródło elektroniczne). Inne wyjaśnienie wiąże się z interpretacją pigułki jako ogólnej tendencji do sprzeciwiania się rodzicom. Myślę jednak, że równie dobrze możemy założyć, iż matka Alicji była kobietą liberalną - być może dała córce środki antykoncepcyjne, które i tak nie uchroniły jej przed niechcianą ciążą. Możliwe też, że dziewczyna cierpi na zaburzenia psychiczne, a matka podaje jej nieskuteczne środki

3 Wszystkie tłumaczenia, o ile nie wskazano inaczej, pochodzą od autorki artykułu. 
przepisane przez lekarza. Wreszcie - być może Alicja jest narkomanką, a matka na własną rękę próbuje przeprowadzić detoks.

Wydaje się, że w kontekście kultury lat sześćdziesiątych wszystkie interpretacje mogą być prawdziwe. Dla bohaterki nie ma jednak odwrotu. Każda pigułka staje się rodzajem inicjacji. Dziewczyna podąża za królikami (chasing rabbits) i spada. Warto zwrócić uwagę na użytą w tekście liczbę mnogą (rabbits), która stanowi odwołanie do wyrażenia chasing the dragons, co z kolei w slangu hippisowskim oznacza palenie opium (Chasing the dragon, źródło elektroniczne). Króliki w kontrkulturze hippisowskiej interpretowane były jako personifikacja LSD, pigułki-przewodnika Biały Królik odpowiada zatem białej tabletce LSD.

"You know, you're goin' to fall" (Wiesz, że wpadniesz) - śpiewają Jefferson Airplane. I oczywiście tak się dzieje. Alicja jest świadoma uczestnictwa w tzw. tripie, nie może mu jednak zapobiec. Gdy jej osobiste „wrota percepcji” otwierają się, wkracza w krainę wiedzy i absurdu. Słowo fall ewokuje też inne znaczenia - w co „wpada” Alicja? W wir epoki? Staje się dzieckiem kwiatem, czyli przyjmuje wszystkie zagrożenia i niepokoje związane z kontrkulturą lat sześćdziesiątych? Może wpada w narkotykowy nałóg? Jednocześnie zapada się w wewnętrznym świecie logiki snu, tak naprawdę odrzuca wszelką racjonalność na rzecz absurdu ${ }^{4}$. Wkracza w sam środek halucynacji, poszerzonej świadomości, alternatywnej onirycznej rzeczywistości.

Interesujący motyw pojawia się w trzecim i czwartym wersie drugiej zwrotki "Tell'em a hookah smoking Caterpillar / Has given you the call" (Powiedz im, że Gąsienica, co pali fajkę / Wezwał cię tu). Ludzie pod wpływem środków odurzających często słyszą głosy. Jest to także objaw choroby psychicznej, niekiedy interpretowany przez osoby religijne jako wizje. Czy Alicja przybywa na wezwanie Pana Gąsienicy? Kim on jest?

Pan Gąsienica, palący fajkę (opium) na halucynogennym grzybie, to niejako trzystopniowa figura symboliczna. W starożytnym Rzymie gąsienicę uważano za symbol nieśmiertelnej duszy, zaś w Indiach symbolizuje ona wędrówkę dusz (Catepillar Symbolism, źródło elektroniczne). Być może bohater jest kimś w rodzaju strażnika - utrzymuje świat czarów w harmonii, jednak to Alicja, osoba z zewnątrz, w momencie zagrożenia przybywa, by przywrócić ład wewnętrzny. Gąsienica siedzi jednak grzybie, często przedstawianym jako muchomor (który ma właściwości halucynogenne), i pali fajkę - opium. Dopiero odpowiednie atrybuty: miejsce, w którym przebywa i które oddziałuje na nią z zewnątrz, oraz artefakt: fajka, z której wdycha dym (ten działa od wewnątrz), pozwalają na pełne zakorzenienie się w wykoślawionej, psychodelicznej rzeczywistości.

W utworze pojawiają się też odwołania do szachownicy w kontekście wyboru konkretnego środka halucynogennego - muchomora. Umysł będący pod wpływem

4 Logika snu to oczywiście oksymoron, stan oniryczny charakteryzują bowiem absurdalność, chaos, zaburzenia praw fizycznych. 
takiego bodźca zwalnia swój bieg. Protagonistka może więc wygrać partię szachów, symbolicznie rozumianą jako grę o życie, gdyż czas zwolnił i ona sama znajduje się w innej rzeczywistości: „And you've just had some kind of mushroom / And your mind is moving low" (I oto otrzymałaś pewien grzyb / Twój umysł zwalnia).

Również Biały Rycerz i Królowa pełnią ważne funkcje. Królowa Kier ścina głowy, zabija (może być także środkiem narkotycznym, który powoduje nieodwracalne zmiany w organizmie), zaś Biały Rycerz posiada umiejętność artykułowania zdań wstecz.

Fantastyczność wydarzeń podkreśla też fragment: „When logic and proportion / Have fallen sloppy dead" (Gdy logika i proporcje / Niedbale wpadły w śmierć) - Kraina Czarów to bowiem miejsce szczególne, rządzące się własną logiką, odmienną od tej, jaką znamy.

Interesująca jest perspektywa narracyjna przyjęta w piosence. Podmiot mówiący zwraca się do słuchacza/czytelnika, nieustannie podkreślając, że we wszystkich sprawach należy pytać Alicję (słynna fraza "Go Ask Alice”). Środki, które zażywa dziewczyna, dały jej dostęp do wiedzy. Możemy ją zapytać o wszystko, gdyż Kraina Czarów to miejsce nieograniczonej wiedzy, rodzaj nadświata, raju dostępnego jedynie tym, którzy podążają drogą narkotycznego tripu.

Nie tylko amerykański zespół psychodeliczny wpadł na taki pomysł. Rolę przewodnika Alicja pełni również w piosence Lucy In The Sky With Diamonds zespołu The Beatles z roku 1967, która znalazła się na słynnym albumie Sgt. Pepper's Lonely Hearts Club Band.

Według legendy utwór ten opisuje doświadczenie narkotyczne, gdyż pierwsze litery najważniejszych słów tworzą skrót LSD. Sam wokalista zaprzeczył temu (Sheff 182), a w 1980 roku wskazał na inspirację Alicją w Krainie Czarów, ważną dla niego książką, a konkretnie sceną z drugiej części przygód Alicji - Through The Looking Glass, w której dziewczynka znajduje się na łodzi. Zinterpretował tę scenę następująco:

It was Alice in the boat. She is buying an egg and it turns into Humpty-Dumpty. The woman serving in the shop turns into a sheep and the next minute they are rowing in a rowing boat somewhere and I was visualizing that. (Oto Alicja znalazła się w lodzi. Kupuje jajko, które staje sie Humptym Dumptym. Ekspedientka w sklepie zamienia się w owcę, a w następnej minucie wiosłują razem gdzieś tam na wioślarskiej łodzi. Tak to sobie wyobraziłem) (Sheff 181).

Natomiast Paul McCartney, współtwórca tekstu, dodał:

We did the whole thing like an Alice In Wonderland idea, being in a boat on the river ... Every so often it broke off and you saw Lucy in the sky with diamonds all over the sky. This Lucy was God, the Big Figure, the White Rabbit (Zrobiliśmy rzecz według pomy- 
słu z Alicji w Krainie Czarów, która znalazła się w łodzi na rzece... Po pewnym czasie przeobraziła się i widzisz Lucy na niebie z diamentami dookoła niej. To Lucy, która jest Bogiem, Wielką Postacią, Białym Królikiem...) (Aldridge 19-24).

O ile w przypadku piosenki zespołu Jefferson Airplane można było odnaleźć bezpośrednie analogie między tekstem a utworem Carrolla, a także sytuacją z tekstu a sytuacją społeczną i kulturową lat sześćdziesiątych, w przypadku Beatlesów (tak będzie również w piosence I Am The Walrus) jest to niemożliwe. Wielopoziomowe metafory, porównania i zabawy językowe pozwalają na mnożenie interpretacji i nigdy nie można być pewnym, która z nich będzie prawdziwa.

Autorzy piosenki zwracają się bezpośrednio do czytelnika/słuchacza. Odbiorca musi wyobrazić sobie siebie samego w łodzi na rzece - to podstawowy punkt orientacyjny, miejsce, w którym rozpoczyna się historia. Warto odnotować, że w dziele Carrolla również płynie rzeka (powstała z łez). Tutaj co prawda nie wykorzystano tego motywu, lecz inne elementy świata przedstawionego wyraźnie wskazują na surrealistyczność krainy, w której rosną mandarynkowe drzewa, a niebo zrobione jest $\mathrm{z}$ marmolady. Szybko jednak pojawia się przewodniczka, która wzywa adresata „z zewnątrz" - „Somebody calls you, you answer quite slowly / A girl with kaleidoscope eyes" (Ktoś woła cię, odpowiadasz wolno / Dziewczyna o kalejdoskopowych oczach).

Wyrażenie "kalejdoskopowe oczy" może wskazywać na głębię widzenia oraz różne stopnie percepcji świata, wielopoziomowość. Są one w pewnej mierze jak promienie rentgenowskie, przenikające nie tylko dziwną rzeczywistość, ale i tego, na kogo patrzą. Zauważmy, że osoba lub osoby, o których mowa w piosence, nie wzywają Alicji-przewodniczki (można założyć, że o nią tu chodzi) jako pierwsze to ona przybywa, niejako odczytując intencję podróżników. W piosence White Rabbit podmiotem przywołującym był Gąsienica, tu jego rolę przejęła dziewczyna „ze słońcem w oczach" (,with the sun in her eyes”). Jednocześnie oczy Alicji są rodzajem zwierciadła, w którym Kraina Czarów przeobraża się i zmienia, są od powiednikiem "dziwów". Dziewczyna znika niemal tak szybko, jak się pojawia, pozostawiając odbiorcę wśród żółtych i zielonych kwiatów z celofanu, które rosną nad jego głową.

W drugiej strofie sytuacja dodatkowo się komplikuje - dziewczyna pojawia się ponownie, a odbiorca podąża za nią aż do mostu zrobionego z fontanny, na którym bujające się konie jedzą marshmellows - słodkie pianki. „Everyone smiles as you drift past the flowers" (Wszyscy się uśmiechają, gdy dryfujesz między kwiatami) - stwierdza tajemniczy podmiot. Kwiaty są wysokie niczym wieże, co może świadczyć o tym, że w czasie, gdy rozgrywa się akcja, Alicja jest po wypiciu napoju zmniejszającego.

Na brzegu rzeki pojawiają się też taksówki z gazet, które zabierają podróżujących do nieba. Ostatnia zwrotka przenosi odbiorcę na stację kolejową, gdzie stoi on z bagażami z plasteliny oraz krawatami z lustra. Przy drzwiach obrotowych czeka przewodniczka. 
Świat przedstawiony jest $\mathrm{w}$ jeszcze większym stopniu niż pierwowzór pozbawiony jakichkolwiek związków przyczynowo-skutkowych. Czas płynie szybko, gdyż słuchacz/czytelnik nieustannie zmienia miejsca pobytu, prawdopodobnie nie jest to też czas linearny - dziewczyna z kalejdoskopowymi oczyma, nazywana tu Lucy (na niebie z diamentami - „in the sky with diamonds”) pojawia się i znika nagle, jakby przejęła rolę Białego Królika. Dochodzi zatem do kontaminacji kilku postaci. Lucy to Alicja, Biały Królik a nawet Pan Gąsienica. Co ważne, jej świat jest sztuczną rzeczywistością - plastelina, szkło, pianki, gazety, plastik. W większości są to materiały nietrwałe, łatwe do uszkodzenia (szkło, gazety). Niektóre są naturalne (papier, woda), cechują się plastycznością (plastelina). Jedynym wyróżniającym się tworzywem jest plastik, stop innych tworzyw, który wskazuje na nieprawdziwość i sztuczność świata. Ewokuje on krainę, która składa się z pozornie absurdalnych, lecz pasujących do siebie elementów.

Psychodelia Alicji-Lucy jest inna, wynika z wyobraźni. Nawet jeśli czasoprzestrzeń jest zaburzona, jest to naturalne. Kraina Czarów Lucy zbudowana jest w dużej mierze z produktów spożywczych, które nie są jednak syntetyczną tabletką, są naturalne, ale poza Alicją i czytelnikiem/słuchaczem nie ma w niej nikogo. Jest to zatem kraina jednostkowej wyobraźni dziecka nieskażonego interpretacją czy nadinterpretacją, pełna metaforycznej i dosłownej słodyczy, posiadająca najwyraźniej znudzoną, lecz wytrwałą przewodniczkę-penetratorkę rzeczywistości.

\section{Alicja - Ta, Której Nie Ma}

Chociaż wiele transformacji Alicji w Krainie Czarów z lat sześćdziesiątych pokazuje bohaterkę aktywną, która posiada świadomość własnej tożsamości i pewną wiedzę na temat tego, co dzieje się wokół niej, pojawiają się też Alicje zagubione, które z jakichś powodów albo fizycznie opuściły Krainę Czarów i teraz do niej wracają, albo przebywają w niej, lecz utraciły część siebie. Symboliczna bądź fizyczna nieobecność Alicji zmienia strukturę Krainy Czarów oraz znacząco wpływa na innych mieszkańców świata przedstawionego.

O takim przypadku śpiewa zespół The Incredible String Band w piosence Alice Is A Long Time Gone. Tutaj surrealizm ewokuje jedynie postać zaczerpnięta bezpośrednio ze świata Carrolla - Biały Królik. Jest to oczywiście figura obcego ${ }^{5}$, o której będzie mowa w kolejnym rozdziale, jednak w tym wypadku jego wypowiedź ma na celu uwypuklenie nie tyle obcości doświadczenia, co raczej ludzkich emocji - Królik

5 Mam tu na myśli przede wszystkim ujęcie Innego/Obcego w filozofii Emmanuela Levinasa, dla którego momentem przełomowym w określeniu tożsamości i podmiotowości na linii ja-Inny jest znalezienie się "twarzą w twarz” i przymus komunikacji, która ujawni ową inność. Jest to szczególnie istotne w momencie zestawienia Alicja-Lustro, gdzie tak naprawdę "nadanie twarzy” pozwala na wyzwolenie od obcości. 
tęskni za dziewczyną z Londynu, której od dawna nie ma. Zniknęła, ponieważ do Krainy Czarów powraca jako "grown up lady from London Town" (dziewczyna z Londynu, która dorosła). Tajemniczy podmiot każe Królikowi się uśmiechać, podczas gdy tamten płacze i śpiewa smutne piosenki. W refrenie powtarzają się słowa: "Alice is gone" (Alicja odeszła). Forma gone oznaczać może zarówno kogoś, kto wyjechał, jak i kogoś, kto umarł.

Alicja w świecie rozpaczającego Królika byłaby raczej Tą, Która Umarła. Chociaż powraca po siedmiu latach, nie jest już bowiem tą samą osobą, którą on tak bardzo pokochał.

W drugiej strofie Biały Królik wymienia cechy dawnej Alicji: była piękna, miała płowe włosy, błyszczące oczy, słodki głos i śnieżnobiałą suknię, a jednocześnie podkreśla, jak bardzo ją kochał i za nią tęsknił. Cała sytuacja budzi pewne wątpliwości, a nawet kontrowersje. Po pierwsze - jak bardzo Kraina Czarów musiała ulec zmianie wraz z pojawieniem się dorosłej dziewczyny? Wyobraźnia Alicji z pewnością się zmieniła. Nie jest powiedziane, czy Alicja zachowała wrażliwość dziecka, czy też może musiała użyć jakichś środków halucynogennych, by wrócić. Problemem jest jednak nie jej siedmioletnia nieobecność, lecz powrót. Ponowne pojawienie się starej-nowej Alicji zaburza strukturę Krainy Czarów. Widzimy to na przykładzie Królika - przyjaciela, który nie może pogodzić się z faktem, że osoba, którą widzi, zmieniła się. Czy Alicja nie ma już jasnych włosów, błyszczących oczu i słodkiego głosu? Czy ubiera się wyzywająco, a może jest naga? Czy zbrzydła? Dlaczego tak naprawdę Królik nie potrafi zaakceptować dorosłej Alicji?

Nie sposób nie odnieść się do kwestii etycznych zaistniałej sytuacji. Pomijając fakt, że w książce Carrolla przyjaźń między Królikiem a Alicją nie została uwypuklona, tym bardziej nie wprowadzono tam uczucia romantycznego, w Alice Is A Long Time Gone Alicja-dziecko opisana została niczym Lolita. Miłość Królika do dawnej Alicji wydaje się czysto fizyczna. Gdyby było inaczej, rozpaczający bohater zwróciłby uwagę na cechy charakteru czy umysłu. W dodatku to uczucie obsesyjne, graniczące z obłędem: "I would exchange my coat of fur / If time would turn or waters burn / I'd wish you back the way you were" (Zmieniłbym mój futrzasty płaszcz / Gdyby czas zawrócił lub zapłonęła rzeka / Chciałbym, byś była taka jak kiedyś).

Podobnie zostaje opisana Alicja w Through The Looking Glass zespołu The Monkees, gdzie również pojawiła się perspektywa obcego - tym razem podmiotem mówiącym jest Lustro. U Carrolla pojawia ono się w nazwie drugiej części Alicji, zatytułowanej właśnie Through The Looking Glass.

"You call my name when you run for protection" (Wołasz mnie po imieniu, gdy szukasz ochrony) - w ten sposób Lustro zwraca się do Alicji, stając się w ten sposób przewodnikiem. W drugiej części przygód Alicji lustro zastępuje króliczą norę, lecz o ile metafora króliczej nory związana była z tym, co zewnętrzne, nad czym można mieć kontrolę (np. zażycie lub niezażycie pigułki LSD), lustro to raczej miejsce wewnętrzne, metafora rozpadu osobowości oraz choroby psychicz- 
nej (np. schizofrenii) czy zaburzeń takich jak borderline lub choroba afektywna dwubiegunowa ${ }^{6}$.

W utworze Lustro zapewnia ochronę przed światem zewnętrznym i jego problemami, ale także przed Alicją jako samą sobą. Dziewczyna jest jednak odbiciem zwierciadło, choć próbuje, nie może jej dosięgnąć - ona natomiast spogląda przez nie na swoje życie.

Podobnie jak w Alice Is A Long Time Gone, tak i tu pojawia się motyw miłości między obcym a człowiekiem. Alicja kocha Lustro - „I think you love me by the way you come on girl" (Po tym, jak do mnie przychodzisz, sądzę, że mnie kochasz). Czy jest to jednak miłość do obcego? Wydaje się, ze jest to raczej metafora próby scalenia roztrzaskanej tożsamości - Alicja kocha samą siebie, lecz jest podzielona, może zatem darzyć uczuciem tylko pewną część, swoje alter ego. Można również zapytać, czy miałaby to być miłość narcystyczna. Lustro odwzajemnia uczucie: "I still love you, girl” (Wciąż cię kocham, dziewczyno) - mówi, zachęcając, by nadal w nie spoglądała. Lecz istnienie Alicji jest iluzoryczne: „If I turn away for a minute, you're gone, girl" (Jeśli odwrócę się na minutę, odejdziesz, dziewczyno). Warunkiem istnienia Alicji jest zatem istnienie Lustra. Oba byty współistnieją i uzupełniają się wzajemnie.

Psychodelia $\mathrm{w}$ tej piosence jest $\mathrm{w}$ pewnym sensie ewokowana przez opisywane doświadczenie. Wyobraźnia lub osobowość Alicji ulega rozwarstwieniu, zupełnie jakby dziewczyna cierpiała na rozdwojenie jaźni. Może być to stan halucynacji bądź snu, lecz kojarzy się on przede wszystkim z chorobą psychiczną.

Sytuacja braku Alicji pojawia sie też w piosence Who Planted Thorns In Miss Alice's Garden? Toma Northcotta z 1967 roku. I tutaj podmiot nie ujawnia swej tożsamości. W stosunku do Alicji nie przybiera jednak tonu zakochanego - nazywa dziewczynę miss Alice - panną Alicją, co świadczy albo o wyjątkowym szacunku, albo o niższej pozycji mówiącego.

Słowa otwierające piosenkę: "Who planeted thorns in miss Alice's garden?" (Kto zasadził ciernie w ogrodzie panny Alicji?) powtarzają się w całym tekście. Już samo wyrażenie „ogród (panny) Alicji” wskazuje na zakorzenienie postaci w świecie przedstawionym. Skoro panna Alicja posiada ogród, to znaczy że albo ktoś jej go podarował, albo sama postanowiła go uprawiać. Idąc dalej tym tropem - jeśli posiada ogród, musi mieć również dom, a więc mieszkać w Krainie Czarów. Nie jest przewodniczką lub kimś, kto przychodzi z wizytą, lecz jest obywatelką. Jest swoja, tutejsza, zadomowiona.

Cały utwór składa się z pytań, na które podmiot nie znajduje odpowiedzi. Dlaczego Alicja nosi czarne ubrania? Czy jest w żałobie? Czy umarł ktoś bliski? Czy jest

6 Borderline (osobowość z pogranicza) to zaburzenie sytuujące się pomiędzy nerwicą a schizofrenią, zaś choroba afektywna dwubiegunowa to połączenie manii i depresji, które objawiają się naprzemiennie. 
to śmierć realna, czy może śmierć symboliczna? Czy Alicja opłakuje swoje dawne życie? A może w Krainie Czarów doszło do pewnych nieodwracalnych przemian i płacze tak, jak Biały Królik opłakiwał swą dawną ukochaną w poprzednio omawianej piosence? Gdzie zniknęło to, co miękkie i dlaczego stało się twarde? („Where is the softness and why did it harden?").

Z pewnością Alicja doświadczyła jakiejś straty - podmiot wiersza zwraca się do niej z pociechą - nie powinna martwić się nieszczęściem, lecz cieszyć z wyboru, gdyż lepiej coś wybrać i stracić, niż nigdy tego nie doznać.

W kolejnych zwrotkach pętla pytań się zacieśnia: kto rzucił kamieniem w okno panny Alicji i zniszczył podłogę? Dokąd odszedł Van Gogh i czemu ją opuścił? Co stało się z kluczem do drzwi? Kto podarł jej rysunki lub zdjęcia? Kto narysował imiona na chodniku przed jej domem? A wreszcie - kto nie powiedział jej, jakie panują reguły gry?

Stopniowanie napięcia wiąże się z powolnym dochodzeniem do prawdy, jaka kryje się za owymi pytaniami - prawdopodobnie chodzi o chorobę Alicji, utratę tożsamości, być może także wspomnień. Nie wiemy, czy bohaterka sama dokonuje aktów wandalizmu, chociaż jest to prawdopodobne. Jeśli tak - czyni to pod wpływem środków halucynogennych albo właśnie choroby psychicznej. Być może jednak zniszczenia pochodzą od kogoś z zewnątrz. Z pewnością trzeba stwierdzić, że hipoteza o zakorzenieniu Alicji w świecie przedstawionym staje się coraz mniej pewna. Alicja należy do tego świata jedynie pozornie, jest definiowana przez stan posiadania, który drastycznie się kurczy lub zostaje w jakiś sposób sprofanowany -jej chodnik, okno, ogród, ubrania. Ceną za posiadanie dóbr materialnych jest tu utrata samej siebie - obłęd, rozdwojenie jaźni, stan egzystencjalnej niepewności.

Chociaż w piosence nie ma bezpośredniego odwołania do narkotyków, a świat przedstawiony sam $\mathrm{w}$ sobie nie budzi skojarzenia z psychodelią (nie wskazuje na to także język utworu), wydaje się, że doświadczenie psychodeliczne Alicji jest już w czwartym stadium, by przywołać klasyfikację Erowid. Jej osobowość rozpadła się, zatem opis poprzednich poziomów związanych z odmiennych postrzeganiem kolorów czy kształtów byłby bezzasadny.

\section{Mieszkańcy Krainy Czarów}

Chociaż w większości narracji muzycznych opartych na prozie Carrolla pojawia się Alicja, zdarzają się historie przedstawiające rzeczywistość z zupełnie innej perspektywy - wspomnianej już perspektywy obcego. Jedną z najbardziej znanych a zarazem najbardziej niezwykłych reprezentacji tego typu jest I Am The Walrus Beatlesów. Tytułowy Mors, bohater Through The Looking Glass, opowiada o Krainie Czarów z własnej perspektywy. W jego świecie nie ma Alicji, pojawiają się jednak inne postaci - między innymi Humpty Dumpty. 
Piosenka I Am The Walrus powstała w 1967 roku na potrzeby filmu Magical Mystery Tour. John Lennon przyznał, że pierwsze dwa wersy napisał w trakcie narkotycznego tripu. W 1980 roku podczas wywiadu dla magazynu „Playboy” wyjaśnił genezę piosenki następująco:

The first line was written on one acid trip one weekend. The second line was written on the next acid trip the next weekend, and it was filled in after I met Yoko... I'd seen Allen Ginsberg and some other people who liked Dylan and Jesus going on about Hare Krishna. It was Ginsberg, in particular, I was referring to. The words "Element'ry penguin" meant that it's naïve to just go around chanting Hare Krishna or putting all your faith in one idol. In those days I was writing abscurely, à la Dylan (Sheff 184).

(Pierwszy wers został napisany w jeden weekend, podczas narkotycznego tripu. Drugi podczas innego tripu w następny weekend, a uzupełniłem wszystko, gdy spotkałem Yoko... Znałem Allena Ginsberga i innych ludzi, którzy lubili Dylana i Jezusa, który stał się jak Hare Krishna. Tak naprawdę to odwoływałem się do Ginsberga. Słowa element'ry penguin wyrażały całą naiwność, jaka przejawia się w recytowaniu mantry Hare Krishna czy pokładaniu wiary w jednym idolu. W tamtych czasach pisałem w sposób absurdalny, w stylu Dylana).

Podmiotem mówiącym w tekście jest Mors z drugiej części przygód Alicji. Jako nieczłowiek automatycznie jest uznawany za obcego. Jego doświadczenie nie jest doświadczeniem człowieka, a obcość ewokowana jest na wiele sposobów. Dziwaczne metafory, rozpad języka, pozbawiony zasad nawet elementarnej logiki świat sprawiają, że słuchacz/czytelnik ma prawo poczuć się bardziej zagubiony niż w którejkolwiek wersji Alicji.

„I am he as you are he as you are me and we are all together" (Jestem on, jak i ty jesteś on, i jak ty jesteś mną, jesteśmy wszyscy razem) - śpiewają Beatlesi. Następuje rozpad tożsamości i osobowości bohatera - jaźń ulega rozbiciu. Należy pamiętać, iż to, co dziwne z ludzkiego punktu widzenia, może być całkiem naturalnym doświadczeniem obcego. Odbiorca od początku ogląda skrajnie jednostkowe doświadczenie rozpadu jaźni wyłącznie z zewnątrz.

Zastanawiająca jest deklaracja, która pojawia się w refrenie: „I'm crying” (Płaczę) - oznajmia Mors. Nie wiemy, z jakiego powodu płacze bohater: ze szczęścia, z rozpaczy, a może jego doświadczenie jest tak głębokie, że jedynie w ten sposób może wyrazić emocje? Nie wiadomo też, kim są tajemniczy „oni": „See how they run, like the pigs from the sky / See how they fly" (Spójrz jak uciekają, niczym świnie z nieba / Spójrz jak sfruwają). Osoby czy też istoty, o których mowa, znajdują się w ciągłym ruchu. Podmiot doświadcza wraz z nimi nieustannej metamorfozy, obserwując świat podczas przemian. Jego przeżycie związane z natężeniem ruchu jest z pewnością psychodeliczne.

Obcość i stan niepewności egzystencjalnej ujawniają się też w języku. Tekst jest pełny paradoksalnych, często oksymoronicznych porównań, metafor i innych środ- 
ków stylistycznych. Lennon i McCartney podążają tropem Carrolla, który również bawił się językiem, tworząc absurdalne rymowanki.

W kolejnej strofie podmiot czeka na ciężarówkę, siedząc na ziarenku kukurydzy, i wymienia niezwiązane ze sobą wydarzenia i elementy pochodzące "z zewnątrz", spoza świata Alicji, między innymi korporacyjny T-shirt jako symbol kapitalizmu, unifikacji, figurę niemal antyutopijną.

„Man you been a naughty boy, you let your face grow long” (Człowieku, byłeś niegrzecznym chłopcem, pozwoliłeś, by twa twarz wydłużyła się) - zwraca się do słuchacza Mors w dalszej części. Zaburzenie proporcji ciała - wydłużona twarz, która być może jest pyskiem świni (w świetle pierwszej zwrotki oraz zawartych w tekście elementów antyutopii być może uprawnione jest tu przywołanie kontekstu Folwarku zwierzęcego George'a Orwella) - nie jest naturalne, podobnie jak nienaturalne było zmniejszenie się czy nagły wzrost Alicji. Z ust podmiotu pada zresztą oskarżenie - nazywa adresata niegrzecznym chłopcem (naughty boy). Być możeowo zaburzenie proporcji nastąpiło w wyniku zażycia psychodelików, które naruszają harmonię i tak już pozbawionego logiki świata. Ponadto stan, którego doświadcza Mors, może być wynikiem zażycia niedozwolonej substancji przez podmiot.

Istotną figurą $\mathrm{w}$ utworze jest też postać policjanta - być może strażnika lub przewodnika, ludzkiego Pana Gąsienicy. W piosence pojawia się też odniesienie do Lucy In The Sky With Diamonds: „See how they fly like Lucy in the sky” (Spójrz jak fruwają, niczym Lucy na niebie) - intertekstualność w tekście jest zatem podwójna - na absurdalną rzeczywistość Alicji nakłada się nie mniej absurdalna rzeczywistość lat sześćdziesiątych (starcia z policją, zażywanie narkotyków) oraz inne, odrębne rzeczywistości kreowane w tekstach tego czasu.

Kolejne zwrotki są równie niezrozumiałe i utrzymane w tej samej konwencji z oka martwego psa sączy się żółty budyń, pojawia się kapłanka pornografii, która sprzedaje ryby, natomiast niegrzeczny chłopiec zostaje zastąpiony niegrzeczną dziewczyną, która pozbywa się bielizny. Czyżby to była zerotyzowana Alicja?

Z ważniejszych postaci Carrollowskiej Krainy Czarów w piosence przywołano też Pana Gąsienicę: „,Expert textpert choking smokers / Don't you think the joker laughs at you?" (Ekspercie bzdercie, duszący się dymem / Nie sądzisz, że błazen śmieje się z ciebie?) - śpiewają słynni muzycy. Natomiast Mors za każdym razem w refrenie staje się eggman (jajownikiem, lecz nie jajcarzem), co stanowić może nawiązanie do Humpty'ego Dumpty'ego z drugiej części powieści. Dalej Beatlesi śpiewają: „I am the walrus, goo goo g'joob g' goo goo g'joob" - słowa, które przy dużej dozie wyrozumiałości można zrozumieć jako good job (dobra robota), nawiązują do Finnegans Wake Jamesa Joyce'a, najsłynniejszej chyba książki postmodernistycznej, która prawdopodobnie powstała w wyniku inspiracji... Alicja w Krainie Czarów (The Cambridge Companion to James Joyce, 13).

Jednocześnie akcja cały czas powraca do angielskiego ogrodu, w którym siedzi Mors, czekając na słońce. Postać z Krainy Czarów wymyka się z magicznego miejsca, 
by w kolejnej zwrotce udać się do Paryża, pod wieżę Eiffla, gdzie pingwiny śpiewają Hare Krishna, kaszkę manną gotuje się z sardynek, a tajemniczy „oni” kopią Edgara Allana Poe. I Am The Walrus jest więc utworem alicjologicznym jedynie w jakiejś części. Nawiązania do Krainy Czarów, choć istotne, nie są jedynymi. Beatlesi pokazują raczej najważniejsze elementy brytyjskiej kultury - literaturę, obyczaje, a nawet charakterystyczne potrawy (jak pudding).

\section{Jak śpiewa się o Alicji?}

Przegląd tekstów pozwala stwierdzić, że o Alicji z Krainy Czarów śpiewa się przede wszystkim różnorodnie. Oczywiście są takie utwory, w których głównym bohaterem jest Jabberwocky czy Szalony Kapelusznik, jednak moim celem było przedstawienie tych piosenek, w których najważniejsza jest Alicja, a świat przedstawiony definiowany jest przez pryzmat jej obecności lub nieobecności. Analizie poddano również I Am The Walrus Beatlesów ze względu na fakt, iż jest jednym z dwóch najsłynniejszych utworów nawiązujących do uniwersum Krainy Czarów.

W tekstach piosenek czasami widzimy Alicję w działaniu - jak np. w White Rabbit, gdzie wpada do króliczej nory, ale szybko przyswaja wiedzę magiczną lub mistyczną i uznana jest za Tę, Która Wie. Zdarza się też, że Alicja przejmuje inicjatywę i staje się przewodniczką - jak w Lucy..., narzucając tym samym reguły poruszania się po Krainie Czarów. Bywają również Alicje zagubione - bohaterka Alice Is A Long Time Gone wraca po siedmiu latach i zostaje odrzucona, bohaterka z Through The Looking Glass nie potrafi zdefiniować własnej tożsamości, być może cierpi na rozdwojenie jaźni. Podobnie jest z Alicją z piosenki Toma Northcotta - cierpi na demencję lub schizofrenię, traci tożsamość i wspomnienia. Natomiast w I Am The Walrus pojawia się postać rozebranej dziewczyny, nie wiadomo jednak, czy można ją w ogóle identyfikować z tytułową postacią powieści Carrolla.

Alicje z piosenek nie zawsze są małymi dziewczynkami. Z pewnością Lucy jest jeszcze dzieckiem, co znacząco wpływa na konstrukcję rzeczywistości wokół niej, pozostałe bohaterki to nastolatki lub młode kobiety. Dorosłość Alicji, która nie wpłynęła dobrze na jej pozycję w Krainie Czarów, wprost wypominana jest jej w Alice Is A Long Time Gone, a Alicja z Who Planted Thorns... jest być może starszą panią.

Psychodelia tekstów muzycznych o Alicji z lat sześćdziesiątych wiąże się zazwyczaj z opisem Krainy Czarów, którą cechuje brak logiki, chaos, zatracie granic między tym, co realistyczne, a tym co fantastyczne. W I Am The Walrus ewokowana jest przez rozpad języka, obcość bohatera oraz nakładanie się na siebie dwóch rzeczywistości: brytyjskich lat tej dekady oraz Krainy Czarów. W Lucy In The Sky With Diamonds to wyobraźnia dziecka tworzy nastrój dziwności, w White Rabbit mamy do czynienia z narkotykami, zaś w utworach Who Planted Thorns In Miss Alice's Gar- 
den? oraz Through The Looking Glass z chorobą psychiczną lub rozpadem/zwielokrotnieniem osobowości.

Postaci oraz motywy, które pojawiają się najczęściej, odzwierciedlają chyba ogólną tendencję $\mathrm{w}$ operowaniu motywami alicjologicznymi $\mathrm{z}$ obu tomów powieści: sama Alicja jako postać najważniejsza, następnie Biały Królik i Pan Gąsienica w roli przewodników, motyw króliczej nory oraz zaburzenia proporcji ciała (bohaterowie rosną/maleją), Humpty Dumpty, Królowa Kier, Mors, Lustro. Zwykle postaci te nie wychodzą ze swojej roli - wyjątek stanowi dosyć kontrowersyjna postawa królika w Alice Is A Long Time Gone.

O Alicji pisze się różnie, ponieważ różne są stopnie psychodelii lat sześćdziesiątych, różna jest także indywidualna wrażliwość artystów i ich stopień zanurzenia w lekturze. Alicja w Krainie Czarów stała się jednak symbolem tego, co dziwne, niepojęte, podlegające nieustannej fluktuacji znaczeń i sensów, a nawet tego, co perwersyjne, zakryte, wstydliwe, o czym opowiada się przy użyciu metafor i aluzji. I chociaż słuchając piosenek z bohaterką Carrolla w roli głównej, niejednokrotnie można się dziwić, jak daleko poeci i piosenkarze odeszli od oryginału, w gruncie rzeczy Alicja wciąż pozostaje taka sama to Kraina Czarów narzuca konieczność ciągłych przeobrażeń.

\section{BIBLIOGRAFIA}

Aldridge, Alan. „Paul McCartney's Guide to the Beatles' Songbook”. Los Angeles Times Magazine 2 (1968). S. 19-24.

Alice Is A Long Time Gone. Web. [20.11.2015]. <http:// www.metrolyrics.com/alice-is-a-long-time-gone-lyrics-incredible-string-band.html>

Cain, Chelsea. The Hippie Handbook: How to Tie-Dye a T-Shirt, Flash a Peace Sign, and Other Essential Things for the Carefree Life. San Francisco: Chronicle Books, 2004.

Catepillar Symbolism \& Meaning. Web. 20.11.2015. < http://www.universeofsymbolism.com/caterpillar-symbolism.html>

Chasing the dragon. Web. 20.11.2015. <http://www.urbandictionary.com/define.php?term=Chasin$\mathrm{g}+$ the + dragon>

Fensch, Thomas. Alice in Acidland. New York: A.S. Barnes, 1970.

Goldberg, Michael Jay. The Collectible '70s: A Price Guide to the Polyester Decade. Iola: Krause Publications, 2001.

Holm, D.K. [sic!]. Robert Crumb, London: Oldcastle Books, 2005.

I Am The Walrus. Web. 20.11.2015. <http://www.thebeatles.com/song/i-am-walrus>

Levinas, Emmanuel. Inaczej niż być lub ponad istotą. Warszawa: Fundacja Aletheia, 2000.

Lucy In The Sky With Diamonds. Web. 20.11.2015. <http://www.thebeatles.com/song/lucy-sky-diamonds>

McCleary, John Bassett. Hippie Dictionary: A Cultural Encyclopedia of the 1960s and 1970s. Danvers: Ten Speed Press, 2002. 
Murray, Nicolas. Aldous Huxley: A Biography. London: Abacus, 2003.

Online Etymology Dictionary. Web. 20.11. 2015. <http:/ / www.etymonline.com>.

Sheff, David. All We Are Saying: The Last Major Interview with John Lennon and Yoko Ono. New York: St. Martin's Press, 2000.

Songfacts. Web. 20.11.2015. <http://www.songfacts.com/detail.php?id=1250>

The Cambridge Companion to James Joyce. Cambridge: Cambridge University Press, 2004.

The psychodelic experience FAQ. Web. 20.11.2015. <https://www.erowid.org/psychoactives/faqs/psychedelic_experience_faq.shtml\#1>

Through The Looking Glass. Web. 20.11.2015. < http://www.metrolyrics.com/through-the-looking-glass-lyrics-monkees.html>

Wolfe, Tom. The Electric Kool-Aid Acid Test. New York: Farrar Straus Giroux, 1968.

White Rabbit. Web. 20.11.2015. <http:/ / www.songfacts.com/detail.php?lyrics=1250>

Who Planted Throns In Miss Alice's Garden? Web. 20.11.2015. <http://abitlikeyouandme.blogspot. com/2012/02/tom-northcott-who-put-thorns-in-miss.html> 